\title{
OTORITAS PRESIDEN DALAM MENETAPKAN PERATURAN PEMERINTAH PENGGANTI UNDANG-UNDANG (Tinjauan Fiqh Siyasah Dusturiyyah dan Hukum Positif)
}

\author{
Ariska Ade Putra1, Nailur Rahmi² \\ Institut Agama Islam Negeri Batusangkar \\ e-mail: ariskaadeputra4@gmail.com \\ ${ }^{2}$ Institut Agama Islam Negeri Batusangkar \\ e-mail: nailurrahmi@iainbatusangkar.ac.id
}

\begin{abstract}
The problem in this research is how the president's authority indetermining government regulations to replace laws is reviewed from the figh siyasah, a form of urgency that forces the establishment of government regulations to substitute laws according to positive law. The purpose of thisdiscussion is to find out how the president's authority in issuing government regulations in lieu of laws is reviewed from the figh siyasah, a form of urgency that forces the establishment of government regulations in lieu of laws according to positive law.
\end{abstract}

Keywords: Dusturiyyah, Hukum Positif, Otoritas, Perpu

\section{PENDAHULUAN}

Menurut Hukum Tata Negara Islam fiqh siyasah merupakan salah satu aspek hukum Islam yang membicarakan pengaturan dan pengurusan kehidupan manusia dalam bernegara demi mencapai kemaslahatan bagi manusia itu sendiri.

Salah satu bidang dari ruang lingkup fiqh siyasah yaitu siyasah dusturiyyah atau politik pembuatan perUndang-Undangan yang meliputi pengkajian tentang penetapan hukum (tasyri'iyah) oleh lembaga legislatif, peradilan (qadha'iyah) oleh lembaga yudikatif, yang menjalankan Undang-Undang (tanfidziyah) oleh lembaga eksekutif dan administrasi pemerintahan (idariyyah) oleh Birokrsi atau eksekutif (Iqbal, 2014: 4).

Kekuasaan seorang Presiden dalam suatu negara modern selalu didasarkan pada konstitusi yang berlaku di negara tersebut. Sejak kemerdekaan hingga sekarang bangsa Indonesia telah berganti-ganti konstitusi. Mulai dari Undang-Undang Dasar Negara Republik Indonesia Tahun 1945 (Periode 18 Agustus 1945-27 Desember 1949), konstitusi Republik Indonesia Serikat (Periode 27 Desember 1949-17 Agustus 1950), Undang-Undang Dasar Sementara (periode 17 Agustus 1950-5 Juli 1959), kembali ke Undang-Undang Dasar Negara Republik Indonesia Tahun 1945 melalui Dekrit Presiden (periode 1959-1971), Undang-Undang Dasar Negara Republik Indonesia Tahun 1945 (periode 1971-1999), dan terakhir.

Undang-Undang Dasar Negara Republik Indonesia Tahun 1945 (periode 1999-2002). Menurut Ismail Sunny, kekuasaan Presiden berdasarkan Undang-Undang Dasar Negara Republik Indonesia Tahun 1945 meliputi kekuasaan administratif, legislatif, yudikatif, militer, dan kekuasaan diplomatik. Kekuasaan administratif ialah pelaksanaan Undang-Undang dan politik administrasi, kekuasaan legislatif ialah memajukan rencana Undang-Undang dan 
mengesahkan Undang-Undang, kekuasaan yudikatif ialah kekuasaan untuk memberikan grasi dan amnesti, kekuasaan militer ialah kekuasaan mengenai angakatan perang dan pemerintahan, kekuasaan diplomatik ialah kekuasaan yang mengenai hubungan luar negeri, dan kekuasaan darurat (Zamroni, 2015: 2).

Dalam Pasal 22 Undang-Undang Dasar Negara Republik Indonesia 1945 menyebutkan bahwa: (1) Dalam hal ihwal kegentingan yang memaksa, Presiden berhak menetapkan peraturan pemerintah pengganti Undang-Undang, (2) Peraturan Pemerintah itu harus mendapat persetujuan DPR dalampersidangannya yang berikut; (3) Jika tidak mendapat persetujuan maka peraturan pemerintah itu harus dicabut.

Jika mengacu pada Pasal 22 Ayat (1) Undang-Undang Dasar Negara Republik Indonesia Tahun 1945 ini maka jelaslah bahwa sejatinya Peraturan Pemerintah Pengganti UndangUndang merupakan suatu peraturan pemerintah, namun berfungsi sebagai Undang-Undang. Dengan demikian Peraturan PemerintahPengganti Undang-Undang merupakan salah satu instrumen hukum yang dapat ditetapkan oleh Presiden tanpa memerlukan keterlibatan Dewan Perwakilan Rakyat (selanjutnya disingkat "DPR"). Peran DPR dalam konteks Perppu baru terlihat pada Pasal 22 ayat (2) dan ayat (3) Undang-Undang Dasar Negara Republik Indonesia Tahun 1945 yang menegaskan bahwa "peraturan pemerintah itu harus mendapat persetujuan Dewan Perwakilan Rakyat dalam persidangan berikut" dan "jika tidak mendapatkan persetujuan maka peraturan pemerintah itu harus dicabut" (lihat UndangUndang Dasar Negara Republik Indonesia Tahun 1945).

Pasal 22 Undang-Undang Dasar Negara Republik Indonesia Tahun 1945 ini, memberikan "hak" dan "wewenang" bagi pemerintah (Presiden) untuk membuat Peraturan Darurat (noodverordeningsrecht). Peraturan Darurat (Noodverordening) disini bernama Peraturan Pemerintah Pengganti Undang-Undang. Hak membuat peraturan darurat ini hanya boleh digunakan apabila ada hal kegentingan yang memaksa (noodtoestand). Peraturan Pemerintah Pengganti Undang-Undang ini dengan prosedur dan akibatnya mirip dengan UU Darurat dalam UUDS 1950.

Dalam teori-teori yang berkaitan dengan hukum tata negara darurat, disebutkan bahwa "kegentingan yang memaksa" sebagaimana yang dimaksuddalam Pasal 22 Undang-Undang Dasar Negara Republik Indonesia Tahun 1945 lebih menekankan pada aspek kebutuhan hukum yang bersifat mendesak atau urgensi yang terkait dengan waktu yang terbatas.

Menurut Jimly Asshiddiqie, terdapat 3 (tiga) unsur penting yang dapat menimbulkan suatu "kegentingan yang memaksa", yakni: (1) Unsur ancaman yang membahayakan (dangerous threat); (2) Unsur kebutuhan yang mengharuskan (reasonable necessity); dan/atau (3) Unsur keterbatasan waktu (limited time) yang tersedia.

Menurut Bagir Manan, unsur kegentingan yang memaksa harus menunjukkan 2 (dua) ciri umum, yaitu ada krisis (crisis), dan ada kemendesakan (emergency). Menurutnya suatu keadaan krisis apabila terdapat gangguan yang menimbulkan kegentingan dan bersifat mendadak (a grave andsudden disturbance). Kemendesakan(emergency), apabila terjadi berbagai keadaan yang tidak diperhitungkan sebelumnya dan menurut suatu tindakan segera tanpa menunggu permusyawaratan terlebih dulu. 
Parameter adanya kegentingan memaksa sebagai syarat untuk menetapkan Peraturan Pemerintah Pengganti Undang-Undang menurut Putusan Mahkamah Kontitusi Nomor 138/PUU-VII/2009, apabila: (1) Adanya keadaan yaitu kebutuhan mendesak untuk menyelesaikan masalah hukum secara cepat berdasarkan Undang-Undang; (2) UndangUndang yang dibutuhkan tersebut belum ada sehingga terjadi kekosongan hukum, atau ada Undang-Undang tetapi tidak memadai, (3) Kekosongan hukum tersebut tidak dapat diatasi dengan cara membuat Undang-Undang secara prosedur biasa karena akan memerlukan waktu yang cukup lama sedangkan keadaan yang mendesak tersebut perlu kepastian untuk diselesaikan (Rahmawati, 2015: 8-9).

Permasalahan pada tulisan ini adalah bagaimana kewenangan presiden dalam Pasal 22 Undang-Undang Dasar Negara Republik Indonesia Tahun 1945 membuat ataupun menetapkan peraturan pemerintah pengganti Undang-Undang menurut fiqh siyasah dan hukum positif sedangkan presiden termasuk kedalam lembaga eksekutif (tanfidziyah), dan yang mempunyai tugas dan wewenang dalam membuat Undang-Undang adalah badan legislatif (tasrieivah).

\section{METODE PENELITIAN}

Penelitian ini merupakan penelitian hukum normatif atau dapat disebut jugadengan penelitian kepustakaan. Dalam penelitian normatif ini hukum dikonsepkan sebagai apa yang tertulis dalam peraturan perUndang-Undangan (law in books) atau juga hukum dikonsepkan sebagai kaidah atau norma yang merupakan patokan berperilaku manusia yang dianggap pantas. Nilai dan norma merupakan keyakinan dan pandangan yang dianut oleh seseorang atau sekelompok orang di dalam sebuah organisasi atau negara (Putri, 2018: 141). Dalam penelitian hukum normatif ini penulis melakukan penelitian terhadap sinkronisasi hukum yang bertitik tolak dari hukum yang ada, dengan cara mengadakan identifikasi terlebih dahulu terhadap kaidah-kaidah hukum yang telah dirumuskan di dalam perUndang-Undangan tertentu.

Adapun latar penelitian yang penulis lakukan yaitu di perpustakaan dan tempat yang memungkinkan untuk mendapatkan literatur yang berhubungan dengan penelitian penulis. Dalam penelitian kualitatif menjadikan peneliti sebagai instrumen kunci atau utama. Sebagai instrumen kunci, penulis melakukan pengumpulan data dan analisis data. Dalam melakukan

penelitian ini penulis mengumpulkan bahan dari perpustakaan terkait dengan masalah yang penulis teliti.

\section{HASIL DAN DISKUSI}

\section{Kewenangan Presiden Dalam Menetapkan Peraturan Pemerintah Pengganti Undang- Undang Ditinjau Dari Fiqh Siyasah}

Kewenangan merupakan kumpulan dari wewenang-wewenang atau kemampuan untuk melakukan suatu tindakan hukum publik. Kewenangan yang dimaksud disini adalah 
kewenangan presiden dalam menerbitkan Peraturan Pemerintah Pengganti Undang-Undang dimana Peraturan pemerintah pengganti Undang-Undang ini sudah diatur di dalam hierarki peraturanperUndang-Undangan Pasal 7 UU Nomor 12 Tahun 2011 tentang pembentukan peraturan perUndang-Undangan sebagaimana telah diubah dengan UU Nomor 15 Tahun 2019 tentang perubahan atas UU Nomor 12 Tahun 2011 tentang pembentukan peraturan perUndang-Undangan, maka dapat dilihat urutanperaturan perUndang-Undangan mulai dari yang tertinggi kedudukannya yaitu: Undang-Undang Dasar Negara Republik Indonesia Tahun 1945; Ketetapan Majelis Permusyarawatan Rakyat; Undang-Undang/Peraturan Pemerintah Penganti Undang-Undang; Peraturan Pemerintah; Peraturan Presiden; Peraturan Daerah Provinsi; dan Peraturan Daerah Kabupaten/Kota (Penjelasan pasal 7 Undang-Undang nomor 15 tahun 2019)

Presiden sebagai Kepala Negara dan Kepala Pemerintahan mempunyai hak dan kewajiban yang telah ditetapkan oleh Undang-Undang Dasar Negara Republik Indonesia Tahun 1945 sebagai berikut: Menyatakan Presiden Republik Indonesia memegang kekuasaan pemerintahan menurut Undang-Undang Dasar (Pasal 4 ayat 1), mengajukan rancangan

Undang-Undang kepada Dewan Perwakilan Rakyat (Pasal 5 ayat 1), menetapkan peraturan pemerintah untuk menjalankan Undang-Undang sebagaimana mestinya (Pasal 5 ayat 2), presiden memegang kekuasaan tertinggi atas $\mathrm{AL}, \mathrm{AD}$, dan $\mathrm{AU}$ (Pasal 10), presiden dengan persetujuan DPR menyatakan perang, membuatperdamaian, dan perjanjian dengan negara lain (Pasal 11 ayat 1), keadaan bahaya (Pasal 12), Mengangkat konsul dan duta atas pertimbangan DPR (Pasal 13 ayat 1), Presiden memberi grasi dan rehabilitasi dengan memperhatikanpertimbangan Mahkamah Agung (Pasal 14 ayat 1), Presiden memberi amnesti dan abolisi dengan memperhatikan pertimbangan Dewan Perwakilan Rakyat (Pasal 14 ayat 2), presiden memberi gelar, tanda jasa, dan lain-lain tanda kehormatan (Pasal 15), Presiden membentuk suatu dewan pertimbangan yang bertugas memberikan nasihat dan pertimbangan kepada Presiden (Pasal 16), Mengangkat dan memberhentikan menteri-menteri, (Pasal 17 ayat 2), Presiden mengesahkan rancangan Undang-Undang yang telah disetujui bersama untuk menjadi Undang-Undang (Pasal 20 ayat 4), menetapkan peraturan pemerintah sebagai pengganti Undang-Undang dalam hal ihwal kegentingan yang memaksa dengan persetujun DPR (Pasal 22 ayat 1), Mengajukan RUU APBN untuk dibahas bersama DPR dengan memperhatikan pertimbangan DPD (Pasal 23 ayat 2), meresmikan Anggota Badan Pemeriksa Keuangan yang dipilih oleh Dewan Perwakilan Rakyat dengan memperhatikan pertimbangan Dewan Perwakilan Daerah (Pasal 23 F ayat 1), Menetapkan Hakim Agung yang telah disetujui Dewan Perwakilan Rakyat yang diusulkan oleh Komisi Yudisial (Pasal 24 A ayat 3), Mengangkat dan memberhentikan Anggota Yudisial dengan persetujuan Dewan Perwakilan Rakyat (Pasal 24 B ayat 3), Mengajukan tiga orang calon hakim konstitusi dan penetapan Sembilan orang anggota hakim konstitusi (Pasal $24 \mathrm{C}$ ayat 3)(Penjelasan Undang-Undang Dasar 1945).

Kewenangan presiden dalam menetapkan suatu Peraturan Pemerintah Pengganti Undang-Undang diatur dalam Pasal 22 Undang-Undang Dasar Tahun 1945 menyebutkan bahwa Dalam hal ihwal kegentingan yang memaksa,Presiden berhak menetapkan peraturan 
pemerintah pengganti Undang-Undang.

Ketentuan Pasal 22 ayat (1) Undang-Undang Dasar Negara Republik Indonesia Tahun 1945 menentukan adanya prasyarat hal ikhwal kegentingan yang memaksa sebagai penilaian Presiden yang bersifat subjektif. Penilaian Presiden itu akan menjadi objektif apabila dinilai dan dibenarkan adanya oleh Dewan Perwakilan Rakyat (DPR) berdasarkan ketentuan Pasal 22 ayat (2) UUD 1945 Dalam rangka membatasi penggunaan Perppu sehingga dapat mencegah tindakan yang tidak konstitusional, maka sangat diperlukan pengawasan yang ketat dari DPR. Penguatan DPR dalam pengawasan peraturan pemerintah pengganti Undang-Undang.sangat penting dalam rangka memberikan porsi kekuasaan yang seimbang antara Presiden dan DPR sehingga tercipta suatu mekanisme chsecks and balances. Dari uraian di atas, DPR dalam menjalankan fungsi pengawasan terhadap penetapan dan pelaksanaan Perppu harus memperhatikan hal-hal sebagai berikut: Pertama, peraturan pemerintah pengganti UndangUndang harus diajukan dalam persidangan DPR berikutnya diartikan bahwa apabila Perppu dikeluarkan Presiden pada masa sidang pertama DPR, maka Presiden harus mengajukan Perppu tersebut pada sidang kedua DPR. Mengingat keberlakuan Perppu ini hanya bersifat sementara, yaitu maksimal harus diajukan pada persidangan DPR yang berikutnya dan jika Perppu tidak mendapat persetujuan DPR, maka peraturan pemerintah pengganti UndangUndang harus dicabut oleh Presiden;

Kedua, peraturan pemerintah pengganti Undang-Undang yang diajukan pada persidangan DPR, yang harus dinilai pertama-tama oleh DPR yaitu dasar kewenangan Presiden menetapkan peraturan pemerintah pengganti Undang-Undang, apakah sudah memenuhi persyaratan adanya hal ikhwal kegentingan yang memaksa sebagaimana yang dimaksud menurut Pasal 22 ayat (1) UUD 1945. Setelah itu barulah DPR memeriksa Perppu tersebut baik dasar yuridis, sosiologis maupun filosofisnya. Demikian pula, penetapan peraturan pemerintah pengganti Undang-Undang harus sesuai dengan asas-asas pembentukan peraturan perUndang-Undangan yang baik;

Ketiga, peraturan pemerintah pengganti Undang-Undang yang dapat dikeluarkan Presiden adalah Perppu yang ditetapkan pada saat DPR sedang tidak bersidang atau reses. Hal ini penting untuk menjaga bahwa Perppu tersebut tetap dalam pengawasan DPR, baik pada saat penetapan maupun pelaksanaannya;

Keempat, peraturan pemerintah pengganti Undang-Undang harus memuat pengaturan di bidang penyelenggaraan pemerintahan atau administrasi negara dalam rangka melancarkan dan menyelesaikan persoalan pemerintahan. Dalam hal Perppu yang memuat ketentuan ketatanegaraan, hak asasi manusia atau ketentuan pidana maka seharusnya peraturan pemerintah pengganti Undang-Undang yang demikian ditolak oleh DPR;

Kelima, Semestinya ketika peraturan pemerintah pengganti Undang-Undang tidak mendapat persetujuan DPR atau ditolak DPR, maka pada saat itu pula peraturan pemerintah pengganti Undang-Undang dapat dinyatakan batal demi hukum (Penjelasan Pasal 22 UndangUndang Dasar Negara Republik Indonesia Tahun 1945)

Praktek pemerintahan yang dilakukan Muhammad SAW sebagai Kepala Negara tampak pada pelaksanaan tugas-tugas yang tidak terpusat pada diri beliau. Dalam piagam Madinah 
beliau diakui sebagai pemimpin tertinggi, yang berarti pemegang kekuasaan legislatif, eksekutif dan yudikatif. Tapi walaupun pada masa itu orang belum mengenal teori pemisahan atau pembagian kekuasaan, namun dalam prakteknya beliau mendelegasikan tugas- tugas eksekutif dan yudikatif kepada para sahabat yang dianggap cakap dan mampu. Timbulnya berbagai masalah yang dihadapi dan perkembangan wilayah kekuasaan menuntut adanya peta pembagian tugas. Untukpemerintahan di Madinah, Nabi menunjuk beberapa sahabat sebagai pembantu beliau, sebagai katib (sekretaris), sebagai 'amil (pengelola zakat) dan sebagai qadhi (hakim). Untuk pemerintahan di daerah, Nabi mengangkat seorang wali, seorang qadhi dan seorang 'amil untuk setiap daerah atau propinsi.

Hukum Islam pun mengatur tentang hal tersebut. Dalam konsep hukum Islam, hal-hal yang berkaitan dengan pembagian kekuasaan dibahas dalam kajian siyasah dusturiyah. Dalam siyasah dusturiyah, kekuasaan itu dikenal dengan istilah "Majlis Syura" atau "ahl al-halli wa al-aqdi" atau seperti yang disebut Abu A "ela al-Maududi sebagai "Dewan Penasehat" serta alMawardi menyebutnya dengan ahl al-Ikhtiyar.

Kekuasaan (sultah) dalam negara Islam, Abdul Wahab Khallaf membaginya menjadi tiga bagian, yaitu: (1) Lembaga legislatif (sultah tasyriciyah), lembaga ini adalah lembaga negara yang menjalankan kekuasaan untuk membuat Undang-Undang, (2) Lembaga eksekutif (sultah tanfiziyyah), lembaga ini adalah lembaga negara yang berfungsi menjalankan UndangUndang, (3) Lembaga yudikatif (sultah Qada “eiyyah), lembaga ini adalah lembaganegara yang menjalankan kekuasaan kehakiman.

Implementasi pembagian kekuasaan ini dapat kita lihat pada masa khulafaur rasyidin. Pada masa itu kekuasaan Eksekutif dipegang oleh seorang khalifah, kekuasaan legeslatif dipegang oleh Majelis Syuro, dan kekuasaan Yudikatif dipegang oleh Qadhi atau hakim. Kemudian, pada masa khilafah kedua yaitu Umar Bin Khattab pembagian kekuasaan antara Eksekutif, Legeslatif, dan Yudikatif diperinci lewat Undang-Undang. Pada masa ini juga, Umar bin Khattab membuat Undang-Undang yang memisahkan antara kekuasaan eksekutif dan legeslatif, dengan tujuan para qadhi sebagai pemegang kekuasaan yudikatif dalam memutuskan perkara harus bebas dari pengaruh eksekutif (Gusmansyah, 2017: 126).

Dalam Islam kekuasaan eksekutif dikenal dengan istilah al-sulthah al- tanfidziyah yang bertugas melaksanakan Undang-Undang, Pelaksana tertinggi kekuasaan ini adalah pemerintah (kepala negara) dibantu oleh para pembantunya (kabinet atau dewan menteri). Wewenang imam atau kepala negara adalah: menegakkan hukum dan bertindak juga sebagai juru bicara bagimasyarakat di luar wilayahnya, imam menegakkan hukum yang mengatur hubungan antara umatbaik pada masa perang maupun masa perdamaian, mengeluarkan perintah perang, memberlakukan hukum di wilayah-wilayah yang baru diduduki, menghukum umat Islam dan non Islam dalam wilayahnya apabila mereka terbukti melanggar hukum, memutuskan kapan jihad dilakukan atau kapan jihad harus dihentikan, menyarankan kapan umat Islam menerima dan menyetujui perdamaian. Semua kewenangan ini bukan tanpa ada pembatasannya. Imam harus menjalankannya dalam batasbatas hukum tertentu, dengan memenuhi sasaran dan tujuan hukum dengan pihak musuh (Gusmansyah, 2017:177). 
Siyasah Dusturiyah adalah bagian fiqh siyasah yang membahas masalah perUndangUndangan negara. Dalam bagian ini dibahas antara lain konsep-konsep konstitusi (UndangUndang Dasar Negara dan sejarah lahirnya perUndang-Undangan dalam suatu negara), legislasi (bagaimana caraperumusan Undang-Undang), lembaga demokrasi dan syura yang merupakan pilar penting dalam perUndang-Undangan tersebut (Muhammad Iqbal, 2014: 177).

Fiqih siyasah dusturiyah mencakup bidang kehidupan yang sangat luas dan kompleks. Sekalipun demikian, secara umum, disiplin ini meliputi hal-hal sebagai berikut: (1) Persoalan dan ruang lingkup (pembahasan), (2) Persoalan imamah, hak, dan kewajibannya; (3) Persoalan rakyat, statusnya, dan hak-haknya, (4) Persoalan baieat; (5) Persoalan waliyul ahdi; (6) Persoalan perwakilan, (7) Persoalan ahlul halli wal aqdi, (8) Persoalan wuzaroh dan perbandingannya (Djazuli, 2003:47).

Sumber Hukum Siyasah Dusturiyah

1. Al-Qurean

Al-Qur"an adalah sumber pokok aturan agama Islam yang utama dijadikan dasar dalam menentukan hukum. Al-Qurean merupakan kalam Allah yang berisi firman-firman Allah dalam bentuk ragam hukum di dalamnya. Karena Al-Qur'an diyakini berasal dari Allah dan teks-teksnya dianggap suci, maka setiap muslim harus mengakuinya sebagai pondasi segala macam superstruktur Islam. Para tokoh-tokoh muslim banyak mencatat bahwasannya AlQur"an merupakan satu-satunya sumber yang paling tinggi dalam menentukan hukumhukum lainnya, karena Al- Qurean tidak pernah mengalami kondisi dan perubahan apapun walau perkembangan zaman terus berjalan.

\section{Sunnah}

Sunnah secara harfiah adalah suatu praktek kehidupan yang membudaya atau suatu norma perilaku yang diterima secara komunal oleh masyarakat yang meyakininya meliputi segenap ucapan dan tingkah laku Nabi. Proses periwayatan Sunnah biasanya disaksikan oleh beberapa orang yang mengetahui langsung kejadiannya tersebut dan disampaikan dari generasi ke generasi sejak zaman Nabi hingga akhir dari perawi yang meriwayatkannya denganmeneliti sederetan perawi yang berkesinambungan.

3. Ijmae

Dalam hukum Islam, ijma"e merupakan suatu keputusanbersama untuk menentukan suatu hukum yang baik demi kemaslahatan umat dengan cara musyawarah. Musyawarah ini timbul dari pemikiran kalangan ulama, mufti, ahli fikih maupunjajaran pemerintahan. Apabila di dalam musyawarah tersebut ada beberapa orang yang tidak setuju dengan hasil keputusan mayoritas peserta musyawarah, maka ijma"e tersebut dinyatakan batal.

\section{Qiyas}

Qiyas adalah metode logika yang digunakan untuk memecahkan suatu masalah yang berkenaan dengan legalitas suatu bentuk perilaku tertentu dengan cara menetapkansatu kaitan positif atau negatif antara bentuk perilaku yang satu dengan bentuk perilaku yang lainnya dengan suatu prinsip umum. Metode qiyas ini biasanya dipergunakan untuk menentukan hukum yang jelas ada berbagai permasalahan yang banyak dan kompleks. Qiyas biasanya 
menggunakan dalil-dalil Al-Qurean maupun hadist yang sekiranya sama bentuk perbuatan hukum yang dihadapi.

5. Adat kebiasaan suatu bangsa yang tidak bertentangan dengan prinsip-prinsip al-Quran dan Hadist (Jindan, 1995: 51).

Salah satu kebiasaan di dalam masyarakat ketika salah seorang warganya wafat adalah dengan mendoakan mayit secara bersama-sama. Di dalam hadits dijelaskan bahwa doa yang dilakukan sendiri atau bersama-sama merupakan suatu hal yang tidak perlu untuk dipertentangkan (Putri, 2020: 81).

Berdasarkan temuan peneliti kewenangan presiden dalam menetapkan peraturan pemerintah pengganti Undang-Undang tidak sesuai dengan hukum tata negara Islam, karena dalam hukum tata negara Islam mengatur hak dan wewenang seorang imam dalam menetapkan suatu aturan, yang berhak menetapkan suatu aturan adalah al-sulthah altasyri'iyah. Dalam kajian fiqh siyasah, legislasi atau kekuasaan legislatif disebut juga dengan majlis syuro ataupun al-sulthah al-tasyrieiyah, yaitu kekuasaan pemerintah Islam dalam membuat dan menetapkan hukum. Kekuasaan legislatif dalam teori Islam dipandang sebagai lembaga tertinggi dalam negara. Kekuasaaneksekutif dalam Islam di sebut al-sulthah altanfidziyah yang bertugas melaksanakan Undang-Undang. Di sini negara memiliki kewenangan untuk menjabarkan dan mengaktualisasikan perUndang-Undangan yang telah dirumuskan tersebut. Dalam hal ini, negara melakukan kebijaksanaan baik yang berhubungan dengan dalam negeri, maupun yang menyangkut dengan hubungan sesama negara (hubungan internasional). Dalam konsep Fiqh Siyasah, kekuasaan yudikatif ini biasa disebut sebagai Sulthah Qadhaiyyah. Tugas lembaga yudikatif adalah memutuskan perselisihan yang dilaporkan kepadanya dari orang-orang yang berseteru dan menerapkan perUndangUndangan kepadanya dalam rangka menegakkan keadilandi muka bumi dan menetapkan kebenaran diantara orang-orang yang meminta peradilan. Imam merupakan bagian dari sulthah al-tanfidziyah atau lembaga eksekutif hanya menjalankan aturantersebut, sedangkan dalam hukum tata negara indonesia, imam atau presiden berhak menetapkan suatu aturan yang dianggap pentingatau mendesak melalui persetujuan DPR dalam sidang paripurna.

Terdapat beberapa perbedaan kewenangan yang dimiliki antara presiden dan Imam (siyasah dusturiyah), antara lain: (a) Kepala Negara dalam Islam tidak ada kewenangan dalam memillih dan mengangkat anggota Dewan Pertimbangan Agung seperti kewenangan Presiden (b). Kepala Negara dalam Islam tidak ada kewenangan Membentuk Peraturan Pemerintah Pengganti Undang-Undang (c). Kepala Negara dalam Islam tidak ada kewenangan Menetapkan Peraturan Pemerintah Pengganti Undang-Undang (d). Kepala Negara dalam Islam tidak ada kewenangan mengangkat duta dan konsul (e). Kepala Negara dalam Islam tidak ada kewenangan memberi grasi, amnesti, abolisi, dan rehabilitasi (Gusmansyah, 2017: 131).

\section{Bentuk Kegentingan Yang Memaksa Dalam Penetapan Peraturan Pemerintah Pengganti Undang-Undang Menurut Hukum Positif}

Menurut Kamus Besar Bahasa Indonesia pengertian negara adalah organisasi di suatu wilayah yang mempunyai kekuasaan tertinggi yang sah dan ditaati oleh rakyat; kelompok 
sosial yang menduduki wilayah atau daerahtertentu yang diorganisasi di bawah lembaga politik dan pemerintah yang efektif, mempunyai kesatuan politik, berdaulat sehingga berhak menentukan tujuan nasionalnya (Kamus Besar Bahasa Indonesia).

Negara Indonesia adalah negara hukum. Hal ini dinyatakan secara tegas di dalam Pasal 1 ayat (3) Undang-Undang Dasar Negara Republik Indonesia Tahun 1945 pasca amandemen. Indonesia sebagai negara hukum modern (welfare state) dalam rangka mewujudkan tujuan negara yakni memberikan kesejahteraan bagi masyarakatnya dan melindungi hak-hak asasi warga negaranya, harus menganut prinsip utama atau asas pokok yang terdiri atas asas legalitas, asas pengakuan dan perlindungan hak asasi manusia, asas pembagian kekuasaan negara, asas peradilan yang bebas dan tidak memihak, asas kedaulatan rakyat, asas demokrasi dan asas konstitusional.

Dalam praktik penyelenggaraan negara atau pemerintahan sering terjadihal-hal yang tidak normal dalam menata kehidupan kenegaraan, di mana sistem hukum yang biasa digunakan tidak mampu mengakomodasi kepentingan negara atau masyarakat sehingga memerlukan pengaturan tersendiri untuk menggerakkan fungsi-fungsi negara agar dapat berjalan secara efektif guna menjamin penghormatan kepada negara dan pemenuhan hak-hak dasar warga negara (Nuh, 2011: 230).

Dalam teori-teori yang berkaitan dengan hukum tata negara darurat, disebutkan bahwa "kegentingan yang memaksa" sebagaimana yang dimaksud dalam Pasal 22 Undang-Undang Dasar Negara Republik Indonesia Tahun 1945 lebih menekankan pada aspek kebutuhan hukum yang bersifat mendesak atau urgensi yang terkait dengan waktu yang terbatas.

Parameter adanya kegentingan memaksa sebagai syarat untuk menetapkan Peraturan Pemerintah Pengganti Undang-Undng menurut Putusan Mahkamah Konstitusi Nomor 138/PUU-VII/2009, apabila:

1. Adanya keadaan yaitu kebutuhan mendesak untuk menyelesaikanmasalah hukum secara cepat berdasarkan Undang-Undang;

2. Undang-Undang yang dibutuhkan tersebut belum ada sehingga terjadi kekosongan hukum, atau ada Undang-Undang tetapi tidak memadai.

3. Kekosongan hukum tersebut tidak dapat diatasi dengan caramembuat Undang-Undang secara prosedur biasa karena akan memerlukan waktu yang cukup lama sedangkan keadaan yang mendesak tersebut perlu kepastian untuk diselesaikan.

Terkait dengan ketiga syarat kegentingan memaksa tersebut, Mahkamah Konstitusi berpendapat bahwa kegentingan yang memaksa tidaklah terbatas pada adanya keadaan bahaya sebagaimana disebutkan dalam Pasal 12 Undang-Undang Dasar Negara Republik Indonesia Tahun 1945. Mahkamah Konstitusi mengakui bahwa keadaan bahaya dapat menimbulkan kegentingan memaksa, namun keadaan bahaya bukanlah satu-satunya kedaan yang membuat kegentingan memaksa sebagaimana dimaksud Pasal 22 ayat (1) UndangUndang Dasar Negara Republik Indonesia Tahun 1945.

Selanjutnya Mahkamah Konstitusi menimbang bahwa Pasal 22 ayat (1) Undang-Undang Dasar Negara Republik Indonesia Tahun 1945 dapat disimpulkan bahwa materi Perpu seharusnya diatur dalam Undang-Undang, namun karena adanya kegentingan memaksa 
maka Undang-Undang Dasar memberikan hak pada Presiden untuk menetapkan Perpu. Hak ini tidak diberikan kepada DPR karena DPR akan memerlukan waktu lama untuk membahasnya mengingat DPR adalah lembaga perwakilan dimana keputusan ada pada anggota sehingga harus melalui rapat-rapat DPR, keadaan mana yang jika diikuti akan membutuhkan waktu lama untuk dapat disetujui.

Mahkamah Konstitusi menyatakan bahwa Perppu melahirkan norma hukum dan sebagai norma hukum baru Perppu akan melahirkan: (a) status hukum baru, (b) hubungan hukum baru, (c) akibat hukum baru. Norma hukum baru lahir begitu Perppu disahkan dan nasib dari norma hukum tersebut sangat bergantung kepada DPR apakah akan menolak atau menerima Perpu. Namun meski DPR akan menjadi penentu diterima tidaknya Perppu, sebelum dibahas oleh DPR norma yang menjadi kandungan Perpu sah dan berlaku sebagai Undang-Undang (Wardaya, 2010).

Berdasarkan uraian di atas, Parameter adanya kegentingan memaksa sebagai syarat untuk menetapkan Peraturan Pemerintah Pengganti Undang-Undang menurut Putusan Mahkamah konstitusi Nomor 138/PUU-VII/2009 sudah memiliki acuan yang kuat dan mengikat semua aturan yang berlaku, sehingga kegentingan memaksa dalam Undng-Undang Dasar tidak hanya dalam keadaan berbahaya, namun bisa dalam keadaan mendesak yang dianggap perlu dibuat aturan baru. Karena Pasal 22 ayat (1) Undang-Undang Dasar Negara Republik Indonesia Tahun 1945 dapat disimpulkan bahwa materi Peraturan Pemerintah Pengganti Undang-Undang seharusnya diatur dalam Undang-Undang, namun karena adanya kegentingan memaksa maka Undang-Undang Dasar memberikan hak pada Presiden untuk menetapkan Perpu. Hak ini tidak diberikan kepada DPR karena DPR akan memerlukan waktu lama untuk membahasnya mengingat DPR adalah lembaga perwakilan dimana keputusan ada pada anggota sehingga harus melalui rapat-rapat DPR, kedaan mana yang jika diikuti akan membutuhkan waktu lama untuk dapat disetujui.

\section{KESIMPULAN}

Kewenangan presiden dalam menetapkan Peraturan Pemerintah Pengganti UndangUndang ditinjau dari Fiqh Siyasah tidak sesuai dengan hukum tata negara Islam, karena dalam hukum tata negara Islam mengatur hak dan wewenang seorang imam, yang berhak menetapkan suatu aturan adalah al-sulthah al- tasyri'iyah, imam hanya menjalankan aturan tersebut. Sedangkan dalam hukum tata negara Indonesia, imam atau presiden berhak menetapkan suatu aturan yang dianggap penting atau mendesak melalui persetujuan DPR dalam sidang paripurna. Bentuk kegentingan memaksa dalam penetapan Peraturan Pemerintah Pengganti Undang-Undang menurut hukum positif dengan Parameter adanya kegentingan memaksa sebagai syarat untuk menetapkan Peraturan Pemerintah Pengganti Undang-Undnag menurut Putusan Mahkamah Konstitusi Nomor 138/PUU-VII/ 2009 sudah memiliki acuan yang kuat mengikat semua aturan yang berlaku, sehingga kegentingan memaksa dalam Undang-Undang Dasar tidak hanya dalam keadaan berbahaya, namun bisa dalam keadaan mendesak yang dianggap perlu dibuat aturan baru. 


\section{DAFTAR PUSTAKA}

Abdullah, G. (2004). Pengantar Memahami Undang-Undang Tentang Pembentukan Peraturan PerUndang-Undangan. Jurnal Legislasi Indonesia, 1(2), 2-4

Candra, A. (2017). Pemikiran Siyasah Syareiyah Ibnu Taimiyah (Kajian Terhadap Konsep Imamah Dan Khilafah Dalam Sistem Pemerintahan Islam). UIR Law Review, 1(2), 163

Direktorat Jenderal Peraturan PerUndang-Undangan Kementerian Hukum dan HAM, 2-3.

Djazuli. Figh Siyasah Implementasi Kemaslahatan Umat dalam Rambu-rambu Syariah. Jakarta: Kencana.

Fala Tansa, A. (2018). Otoritas Presiden Dalam Menerbitkan Perppu Menurut Fiqih Siyasah. Skripsi. Fakultas Syariah Dan Hukum. Universitas Islam Negeri Syarif Hidayatullah. Jakarta

Febriansyah, I. (2016). Konsep Pembentukan Peraturan PerUndang-Undangan Di Indonesia. Perspektif, 21(3), 223-224.

Gusmansyah, W. (2017). Trias Politica Dalam Perspektif Fikih Siyasah. Al- Imarah: jurnal pemerintahan dan politik Islam, 2(2), 129-130

Hakim, L. (2011). Kewenangan Organ Negara Dalam Penyelenggaraan Pemerintahan. Jurnal Konstitusi, 4(1), 112

Halim, H. (2009). Cara Praktis Menyusun dan Merancang Peraturan Daerah. Jakarta: Prenada Media Group.

Hasan, M. (2014). Aplikasi Teori Politik Islam Perspektif Kaidah-Kaidah Fikih. Madania, 18(1), 99-100

Humaidi, N. (2009). Kepemimpinan Dalam Perspektif Shi,,Ah Kajian Atas Konsep Imamah. Humanity, 5(1), 37

Idris, I. (2009). Islam dan Konstitusionalisme kontribusi Islam dalam penyusunan Undang-Undang dasar indonesia modern. Yogyakarta: antonylib-Indonesia.

Indrati F, Maria. (2007). Ilmu Perundang-Undangan, Jenis, Fungsi Dan Materi Muatan. Jakarta: Kanisius.

Iqbal, M. (2001). Fiqh Siyasah Kontektualisasi Doktrin Politik Islam. Jakarta Selatan: Gaya Media Pratama.

Iqbal, M. (2014). Fiqh Siyasah Kontektualisasi Doktrin Politik Islam. Jakarta: Prenadamedia Group. Ishom, Muhammad. (2017). Legal Drafting. Malang: Setara Press.

Jindan, I. (1995). Teori Politik Islam Telaah kritis Ibnu Taimiyah Tentang Pemerintahan Islam. Surabaya: Risalah Gusti.

Julianthy, M dan Evlyn M. (2018). Pelaksanaan Kewenangan Atribusi Pemerintahan Daerah Berdasarkan Undang-Undang Nomor 23 Tahun 2014 Tentang Pemerintahan Daerah. Jurnal Legislasi Indonesia, 15(2), 4

Junaidi, M. (2018). Hukum Konstitusi Pandangan dan Gagasan Modernisasi Negara Hukum. Depok: PT. Raja Grafindo Persada.

Kansil. (2000). Hukum Tata Negara Republik Indonesia. Jakarta: PT Rineka Cipta.

Marbun. (1997). Peradilan Administrasi dan Upaya Administratif di Indonesia. Yogyakarta: Liberty. Pulungan, S. (1994). Fiqh Siyasah. Jakarta: Raja Grafindo Persada.

Purbacaraka, P, dkk. (1993). PerUndang-Undangan dan Yurisprudensi. Bandung: PT Citra Aditya 
Bakti.

Putri, S. E. (2018). Pemetaan Jaringan Sosial dalam Organisasi: Studi Pada Distributor Tupperware Unit Simabur Indah di Batusangkar Sumatera Barat. Jurnal Antropologi: Isuisu Sosial Budaya, 20(2), 141.

Putri, S. E. (2020). Upacara Kematian Pada Masyarakat Nagari Taluak Kecamatan Lintau Buo Kabupaten Tanah Datar Dalam Perspektif Hukum Islam. Jurnal Ilmiah Syariah, 19(1).

Rahmawati, N. (2015). Tinjauan Figh Siyasah Terhadap Ketentuan "Dalam Hal Ihwal Kegentingan Memaksa Sebagai Syarat Penetapan Perpu Oleh Presiden”. Tesis. Pascasarjana. Universitas Islam Negeri Sunan Ampel. Surabaya.

Ridwan. (2009). Tiga Dimensi Hukum Administrasi dan Peradilan Administarsi. Yogyakarta: FH UII Press.

Samsu, L. (2017). Al-Sultah Al-Tasyrieiyyah, Al-Sultah Al-Tanfiziyyah, Al- Sultah AlQada"iyyah. STAI A-Munawarah Tolitoli, 158.

Syamsuddin, A. (2014). Proses E Teknik Penyusunan Undang-Undang Jilid 2. Jakarta: Sinar Grafika.

Syarief, A. (1997). PerUndang-Undangan,dasar, jenis, dan teknik membuatnya. Jakarta: PT Rineka Cipta.

Syarifin, P, dkk. (2012). Ilmu PerUndang-Undangan. Bandung: CV Pustaka Setia.

Ubaedillah. (2015). Pancasila Demokrasi dan Pencegahan Korupsi. Jakarta: Prenada Media Group.

Undang-Undang Dasar Negara Republik Indonesia Tahun 1945

Undang-Undang Nomor 12 Tahun 2011 tentang pembentukan peraturan perUndangUndangan sebagaimana telah diubah dengan Undang-Undang Nomor 15 Tahun 2019 tentang perubahan atas Undang-Undang Nomor 12 Tahun 2011 tentang pembentukan peraturan perUndang-Undangan

Undang-Undang Nomor 5 Tahun 2017 tentang Aparatur Sipil Negara Perpres 87 Tahun 2014 tentang pelaksanan UU Nomor 12 Tahun 2011 Putusan Mahkamah Konstitusi Nomor 138/PUU-VII/ 2009

Winardi, dan Sirajuddin. (2015). Dasar-Dasar Hukum Tata Negara Indonesia. Malang: Setara Press.

Yendra, A. (2013). Tekhnik Pembuatan Peraturan PerUndang-Undangan. Bukittinggi: Perc Syamza Offset.

Yuliandri. (2013). Asas-Asas Pembentukan Peraturan PerUndang-Undangan Yang Baik. Jakarta: PT Rajagrafindo Persada.

Zada, Khamami dan Mujar Ibnu S. (2008). Fiqh Siyasah Doktrin dan Politik Islam. Jakarta: Erlangga.

Zamroni, M. (2015). Kekuasaan Presiden Dalam Mengeluarkan Perpu. 